\title{
PERLINDUNGAN HUKUM PEKERJA KONTRAK DALAM UPAH MINIMUM PADA HOTEL KELAPA RETREAT \& SPA DI JEMBRANA
}

\author{
Oleh: \\ Aggi Nugroho** \\ I Wayan Wiryawan ${ }^{* * *}$ \\ Program Kekhususan Hukum Bisnis, \\ Fakultas Hukum, \\ Universitas Udayana
}

\begin{abstract}
ABSTRAK
Adapun faktor yang belakangi terjadinya kemiskinan, lemahnya strukur sosial dan ekonomi, kurangnya kesempatan bekerja, pengecualian terhadap orang-orang yang memiliki tingkat perekonomian yang kurang kewaspadaan pekerja untuk mendapatkan pekerjaan. Suatu perjanjian yang telah disepakati oleh para pihak secara tidak langsung akan menjadi undang undang bagi para pihak yang mengikatkan dirinya dan dalam membuat perjanjian harus beritikad baik. Berdasarkan uraian diatas, adapun permasalahan yang dibahas adalah Bagaimanakah perlindungan hukum bagi pekerja dalam pemberian upah yang tidak sesuai dengan UMK di Hotel Kelapa Retreat \& SPA di Kabupaten Jembrana dan Bagaimanakah upaya hukum yang dilakukan pekerja akibat mengalami upah dibawah UMK di Hotel Kelapa Retreat \& SPA di Kabupaten Jembrana.

Metode yang digunakan dalam penelitan ini adalah metode penelitian yuridis empiris, serta jenis pendekatan yang digunakan dalam penelitian ini yaitu pendekatan fakta pendekatan perundang-undangan.

Tujuan dari penelitian ini untuk memahami dan mengetahui pelaksanaan pengupahan yang di berikan terhadap tenaga kerja kontrak dan yang bekerja di Hotel kelapa retreat \& SPA di Kabupaten Jembrana,

Perlindungan hukum bagi pekerja kontrak yang menerima upah di bawah UMK di Hotel Kelapa Retreat \& Spa, sistem pengupahan yang di terapkan tidak sesuai dengan peraturan UMK (Upah Minimum Kabupaten/Kota) yang berlaku sebagaimana

** Aggi Nugroho adalah Mahasiswa Fakultas Hukum Universitas Udayana. Korespondensi :agginugroho@gmail.com

${ }^{* * *}$ I Wayan Wiryawan adalah Dosen Fakultas Hukum Universitas Udayana.
\end{abstract}


mestinya di Kabupaten Jembrana.

\title{
Kata Kunci :Pekerja, Perjanjian Kerja, Upah
}

\begin{abstract}
The factors that support and underlie the occurrence of poverty, weak social and economic structures, lack of employment opportunities, organized crime, violence against people who have low social status, exception against people who have economic levels that are less, less victim's alertness to get a job. In addition, the lack of comprehensive education, which mainly includes education in science, moral education, religious education, and citizenship education. An agreement that has been agreed upon by the parties will indirectly become a law for the parties that bind themselves and in making an agreement must have good intentions. Based on the description above, as for the problems discussed are How is the legal protection for workers in providing wages that are not in accordance with the UMK at Hotel Kelapa Retreat \& Spa in Jembrana district and How is the legal effort carried out by workers due to experiencing wages below the UMK at Hotel Kelapa Retreat \& Spa in Jembrana district.

The method used in this research is an empirical juridical research method, and the type of approach used in this study is the factual approach to the legislative approach. The purpose of this study is to understand the legal protection provided for contract labor that works at Hotel Kelapa Retreat \& Spa in Jembrana district and To find out how to solve problems for contract workers who do not get rights in terms of wages and welfare at Hotel Kelapa Retreat \& Spa in Jembrana district.

Legal protection for contract workers who receive wages below the UMK at Hotel Kelapa Retreat \& Spa the wage system applied is not in accordance with the applicable UMK regulations in Jembrana district.
\end{abstract}

Keywords: Workers, Work Agreements, Wages

\section{PENDAHULUAN}

\subsection{Latar Belakang}

Perlindungan terhadap tenaga kerja dimaksudkan untuk menjamin hak-hak dasar pekerja/buruh dan menjamin kesamaan kesempatan serta perlakuan tanpada diskriminasi atas dasar apapun untuk mewujudkan kesejahtraan buruh dengan 
keluarganya dengan tetap memperhatikan perkembangan kemajuan dunia usaha ${ }^{1}$.

Peran pekerja sebagai modal usaha dalam melaksanakan pembangunan harus didukung juga dengan jaminan hak setiap pekerja $^{2}$, kemampuan bekerja itu sendiri dapat terganggu berbagai halangan atau resiko sosial- ekonomi yang menimpa tenagakerja baik berupa kecelakaan kerja, sakit, hari tua, maupun meninggal dunia ${ }^{3}$. Untuk menanggulangi atau menghindari resiko-resiko tersebut maka diperlukan perlindungan hukum terhadap tenaga kerja kontrak.

Dalam Undang-Undang No 13 Tahun 2003 tentang ketenagakerjaan Pasal 1 angka (4) "Pemberi kerja adalah orang perseorangan, pengusaha, badan hukum, atau badan-badan lainnya yang mempekerjakan tenaga kerja dengan membayar upah atau imbalan dalam bentuk lain".

Pada hakikatnya program pengupahan dan tenaga kerja sebagaimana disebutkan dalam Undang-Undang No. 13 tahun 2013 tentang Ketenagakerjaan untuk memberikan kepastian berlangsungnya arus penerimaan penghasilan keluarga sebagai pengganti sebagian.

Dalam pengupahan yang dimaksud pengupahan minimum pada pada Pasal 89 UU No. 13 tahun 2003 yang menyatakan;

\footnotetext{
${ }^{1}$ I Made Udiana,2015, Kedudukan Dan Kewenangan Pengadilan Hubungan Industrial,Udayana University Press ,Denpasar,h.4

${ }^{2}$ Asri Wijayanti, 2009, Hukum Ketenagakerjaan Pasca Reformasi, Penerbit Sinar Grafika, Jakarta,hal 6

${ }^{3}$ Lalu Husni ,2014, Pengantar Hukum Ketenagakerjaan, Rajawali Pers, Jakarta, h.151
} 
1. Upah minimum sebagaimana dimaksud dalam Pasal 88 ayat (3) huruf a terdiri atas:

a. upah minimum berdasarkan wilayah provinsi atau kabupaten/kota;

b. upah minimum berdasarkan sektor pada wilayah provinsi ataukabupaten/kota.

2. Upah minimum sebagaimana dimaksud dalam ayat (1) diarahkan kepada pencapaian kebutuhan hidup layak.

3. Upah minimum sebagaimana dimaksud dalam ayat (1) ditetapkan oleh Gubernur dengan memperhatikan rekomendasi dari Dewan Pengupahan Provinsi dan/atau Bupati/Walikota.

4. Komponen serta pelaksanaan tahapan pencapaian kebutuhan hidup layak sebagaimana dimaksud dalam ayat (2) diatur dengan Keputusan Menteri.

Pasal 1 angka 30 UU Ketenagakerjaan menentukan bahwa upah tersebut ditetapkan atau dibayarkan menurut suatu perjanjian kerja, kesepakatan, atau peraturan perundangundangan, termasuk tunjangan bagi pekerja/buruh dan keluarganya atas suatu pekerjaan dan/atau jasa yang telah atau akan mereka lakukan. Upah merupakan salah satu sarana bagi pekerja untuk menngkatkan kesejahteraannya ${ }^{4}$.

Mengingat pada Peraturan Gubernur Bali No 91 Tahun 2018 Tentang Upah Minimum Kabupaten/Kota , tertuang pada Pasal 2 bahwa "Upah Minimum Kabupaten/Kota ditetapkan sebagaimana tercantum dalam lampiran yang merupakan bagian tidak terpisahkan dari peraturan gubernur ini".

Peraturan Mentri Tenaga Kerja dan Transmigrasi No 7 Tahun 2013 Tentang Upah Minimum bahwa :

1. Pasal 15

a. Pengusaha dilarang membayar upah lebih rendah dari Upah Minimum yang telah ditetapkan.

b. Upah Minimum hanya berlaku bagi pekerja/buruh yang mempunyai masa kerja dari 1 (satu) tahun.

2. Pasal 16

\footnotetext{
${ }^{4}$ Noor Faiz, 2017, Kolerasi Pengaturan Upah Dengan Investasi Di Indonesia, Jurnal Magister Hukum Udayana Vol. 6, No. 3, September 2017.
} 
a. Upah Minimum wajib dibayar bulanan kepada pekerja/buruh

b. Berdasarkan kesepakatan antara pekerja/buruh atau serikat pekerja/serikat buruh dengan pengusaha, Upah minimum dapat dibayarkan mingguan atau 2 (dua) mingguan dengan ketentuan perhitungan Upah Minimum didasarkan pada upah bulanan.

Perusahaan harus sesuai dengan kondisi keuangan atau perekonomian untuk menentukan upah diberikan kepada pekerja atau buruh. UMK atau dikenal dengan Upah Minimum Kabupaten/Kota sering menjadi sorotan terhadap aspeknya ketenagakerjaan seperti Upah Minimum Kabupaten/Kota yang sering ditetapkan sangat berbeda dengan kenyataanya, sering kali perusahaan memberikan upahnya dibawah minimum sesuai dengan aturan yang ditentukan sehingga pekerja/buruh sering mendapatkan kerugian kesejahteraan bagi pekerja.

Perjanjian kerja mempunyai manfaat yang besar bagi para pihak yang mengadakan perjanjian tersebut. Hal ini hendaknya harus disadari karena perjanjian kerja yang dibuat dan ditaati secara baik akan dapat menciptakan suatu ketenangan kerja, jaminan kepastian hak dan kewajiban baik bagi pekerja maupun pengusaha. Akibat lebih jauh nantinya produktivitas akan perusahaannya dan lebih luas lagi dapat membuka lapangan kerja baru. Suatu perjanjian yang telah disepakati oleh para pihak otomatis akan menjadi sebuah undang - undang bagi para pihak yang mengikatkan dirinya dan dalam membuat perjanjian harus beritikad baik.

Pelaksanaan pada waktu sekarang ini tidak sesuai dengan kenyataan yang ada, tujuan dari adanya reformasi hukum di 
bidang ketenagkerjaan yang dilakukan dengan tujuan untuk memberikan rasa keadilan dan perlindungan teradap buruh/pekerja serta untuk memenuhi amanat Undang-Undang Dasar 1945 yaitu untuk melakukan pembangunan manusia Indonesia seutuhnya dan pembangunan masyarakat Indonesia seluruhnya.

\subsection{Rumusan Masalah}

Berdasarkan latar belakang masalah diatas, maka dapat diangkat beberapa permasalahan yang timbul diantaranya:

1. Bagaimanakah pelaksanaan UMK terhadap tenaga kerja kontrak di Hotel Kelapa Retreat \& SPA di Kabupaten Jembrana?

2. Bagaimanakah peranan dinas tenagakerja terhadap UMK di Kabupaten Jembrana?

\subsection{Tujuan Penelitian}

Tujuan penelitian merupakan sesuatu yang berguna untuk menentukan hasil apa yang akan diperoleh. Pada penulisan suatu karya ilmiah haruslah mempunyai tujuan yang dapat dipertanggungjawabkan. Tujuan peneltian meliputi tujuan umum dan tujuan khusus. Tujuan umum berupa upaya peneliti untuk pengembangan ilmu hokum terkait dengan paradigma science as a process (ilmu sebagai proses). Sedangkan tujuan khusus 
mendalami permasalahan hukum secara khusus yang tersirat dalam rumusan permasalahan penelitian.

\section{ISI MAKALAH}

\subsection{Metode Penelitian}

Metode penelitian hukum empiris adalah suatu metode penelitian hukum yang berfungsi untuk melihat hukum dalam artian nyata dan meneliti bagaimana bekerjanya hukum di lingkungan masyarakat. Dikarenakan dalam penelitian ini meneliti orang dalam hubungan hidup di masyarakat maka metode penelitian hukum empiris dapat dikatakan sebagai penelitian hukum sosiologis. Dapat dikatakan bahwa penelitian hukum yang diambil dari fakta-fakta yang ada di dalam suatu masyarakat, badan hukum atau badan pemerintah.

\subsection{Hasil dan Pembahasan}

\subsubsection{PELAKSAAN PENGUPAHAN UMK TERHADAP TENAGA KERJA KONTRAK DI HOTEL KELAPA RETREAT \& SPA DIKABUPATEN JEMBRANA}

Pelaksanaan upah di hotel kelapa retreat sesuai dengan perjanjian tertulis antara pekerja dengan pengusaha hotel dan adapun upah tambahan yaitu berupa hasil tiping yang diberikan di kumpulkan selama jangka waktu 1 bln dan akan di bagikan oleh karyawan hotel secara merata pada akhir bln.

Istilah upah muncul saat akan atau telah melakukan suatu pekerjaan untuk oranglain. Pekerjaan yang dimaksud boleh jadi diuraikan secara rinci disertai dengan besaran upah yang kita terima sebagai sebuah kesepakatan. Kesepakatan untuk 
melakukan pekerjaan yang dikenal dengan perjanjian kerja. Dalam perjanjian kerja tidak hanya dalam bentuk tertulis tetapi banyak juga yang dibuat secara lisan ${ }^{5}$. Ketika terjadi kesepakatan kerja maka pekerja atau buruh berhak menerima upah, sedangkan orang yang memberi pekerjaan disebut sebagai pemberi kerja ( pengusaha ).

Undang-Undang Republik Indonesia No. 13 tahun 2003 tentang Ketenagakerjaan ,mengatur dengan tegas dan jelas mengenai pengupahan yang diatur pada Bagian Kedua"Pengupahan" tepatnya dimulai dari Pasal 88 sampai dengan Pasal 98. Untuk lebih memberikan penjelasan mengenai pengupahan dikutip secara keseluruhan pada Pasal 88 ayat (1).

Dalam penetapan Upah Minimum tersebut sesuai Pasal 89 ayat (1) dan ayat (2), dibagi menjadi dua yaitu (a). Berdasarkan wilayah Propinsi atau kabupaten/kota, (b).Berdasarkan sektor pada wilayah Propinsi atau kabupaten/kota yang diarahkan kepadapencapaian kebutuhan hidup layak.Sedangkan untuk penetapan Upah Minimum dilakukan oleh Gubernur sebagaimana ditentukan dalam Pasal 89 ayat (3) "Upah Minimum sebagaimana dimaksud pada ayat (1) ditetapkan oleh Gubernur dengan mempertimbangkan rekomendasi dari Dewan Pengupahan Propinsi dan/atau Bupati/Walikota." Ayat (4) "Komponen serta pelaksanaan tahapan pencapaian kebutuhan hidup layak diaturdengan Keputusan Menteri”.

Para pengusaha dilarang membayar upah lebih rendah dari Upah Minimum (sebagaimana dimaksud dalam Pasal 89) namun apabila pengusaha ternyata tidakmampu membayar Upah

\footnotetext{
${ }^{5}$ Zaeni Asyhadie, 2007, Hukum Kerja: Hukum Ketenagakerjaan Bidang Hubungan Kerja, PT. Raja Grafindo Persada, Jakarta. h. 20
} 
Minimum yang telah ditetapkan oleh pemerintah, maka dapat memohon penangguhan yang tata caranya diatur dengan Keputusan Menteri Tenaga Kerja.

Dalam hal kesepakatan dalam penetapan upah antara pengusaha dengan pekerja/buruh atau serikat pekerja/serikat buruh ternyata lebih rendah maka kesepakatan tersebut batal demi hukum dan pengusaha wajib membayar upah pekerja/buruh menurut peraturan perundang-undangan yang berlaku Pasal 92 ayat (1):

"Pengusaha menyusun struktur dan skala upah dengan memperhatikan golongan, jabatan, masa kerja pendidikan dan kompetensi." Ayat (2) :"Pengusaha melakukan peninjauan upah secara berkala dengan memperhatikan kemampuan perusahaan dan produktivitas". Ayat (3) :Ketentuan mengenai struktur dan skala upah diatur dengan KeputusanMenteri”.

Setiap pekerja/buruh berhak memperoleh perlakuan yang sama tanpa diskriminasi dari pengusaha. Pengusaha harus memberikan hak dan kewajiban pekerja/buruh tanpa membedakan jenis kelamin, suku, ras, agama, warna kulit, dan aliran politik.Sikap pengusaha yang memberlakukan upah minimum hanya kepada segelintir karyawan tanpa alasan yang jelas ini dapat dikategorikan sebagai bentuk diskriminasi yang dapat diancam sanksi.

Menurut Pasal 90 ayat (1) UU No. 13 Tahun 2003 tentang Ketenagakerjaan (“UU Ketenagakerjaan") pengusaha dilarang membayar upah lebih rendah dari upah minimum, baik upah minimum (UM) berdasarkan wilayah propinsi atau kabupaten kota (yang sering disebut Upah Minimum Regional, UMR) maupun 
upah minimum berdasarkan sektor pada wilayah propinsi atau kabupaten/kota (Upah Minimum Sektoral, UMS).

\subsubsection{PERANAN DINAS TENAGA KERJA KABUPATEN JEMBRANA TERHADAP UMK}

Dalam penyelenggaraan tugas pokok tersebut, Dinas Kesejahteraan Sosial Tenaga Kerja Dan Transmigrasi Kabupaten Jembrana mempunyai fungsi sebagai :

a. Perumus kebijakan teknis sesuai kewenangan bidang Kesejahteraan Sosial Tenaga Kerja Dan Transmigrasi

b. Penyelenggara urusan pemerintahan dan pelayanan umum bidang Kesejahteraan Sosial Dan Transmigrasi

c. Pembina dan pelaksana tugas di bidang Kesejahteraan Sosial Dan Transmigrasi

d. Pemberi rekomendasi perijinan sesuai bidang Kesejahteraan Sosial Tenaga Kerja Dan Transmigrasi

e. Pelaksana tugas lain yang diberikan oleh Bupati sesuai dengan tugas dan fungsinya.

Berdasarkan hasil wawancara dengan ibu Ni Komang Sudiastri,.SH ,NIP 196707121987032010 , jabatan sebagai Kasi Perlindungan Tenaga Kerja bahwa dinas ketenagakerjaan Kabupaten Jembrana dalam hal pengupahan UMK menjalankan peranan sesuai dengan Undang-Undang 13 Tahun 2003 Tentang Ketenagakerjaan dan Peraturan Mentri No 78 Tahun 2015 Tentang Pengupahan, Dinas Ketenagakerjaan Kabupaten Jembrana selama ini di kabupaten jembrana belum pernah menerapkan sanksi bagi perusahaan yang belum melaksanakan UMK, kalau melaksanakan sangsi sesuai Undang-Undang, banyak persahaan yang tutup dan 
tenaga kerja yang nganggur, prinsip tenaga kerja dengan pengusaha tidak ada gejolak atau masalah tentang upah. Melakukan peringatan secara lisan belum secara tertulis. Disamping itu di Kabupaten Jembrana banyak adanya wirausaha kecil.

\section{PENUTUP}

\subsection{Kesimpulan}

1. Perlindungan hukum bagi pekerja kontrak yang menerima upah di bawah UMK di Hotel Kelapa Retreat \& Spa, sistem pengupahan yang di terapkan tidak sesuai dengan peraturan UMK (Upah Minimum Kabupaten/Kota) yang berlaku sebagaimana mestinya di Kabupaten Jembrana. Dengan kata lain, kesepakatan (konsensus) para pihak kausa-nya harus halal. Sehingga, memperjanjikan upah di bawah upah minimum antara pengusaha dengan pekerja adalah null and void atau batal demi hukum.

2. Upaya hukum yang dapat dilakukan pekerja ketika mendapatkan upah dibawah UMK (Upah Minimum Kabupaten/Kota) dalam pelaksaanya di Hotel Kelapa Retreat \& Spa yakni pekerja memilih menyelesaikan masalah dengan cara musyawarah. Hasil musyawarah antara pihak perusahaan dengan pekerja bedasarkan permasalah upah dibawah UMK (Upah Minimum Kabupaten/Kota) telah mendapatkan kesepakatan bahwa pihak perusahaan akan mengganti kerugian uang sesuai dengan kesepakatan dari musyawarah yang telah dilakukan oleh pihak perusahaan dengan pekerja.

\subsection{Saran}


1. Upah seharusnya mengikut peraturan yang berlaku karena upah merupakan hak-hak dari pekerja untuk memenuhi kebutuhan hidupnya.

2. Pengusaha apabila tidak bisa membrikan gaji sesuai UMK sebaiknya mengajukan permakluman sesuai perturan yang berlaku.

\section{DAFTAR PUSTAKA}

\section{Buku - Buku}

Asri Wijayanti, 2009, Hukum Ketenagakerjaan Pasca Reformasi, Penerbit Sinar Grafika, Jakarta.

I Made Udiana, 2015, Kedudukan Dan Kewenangan Pengadilan Hubungan Industrial,Udayana University Press ,Denpasar.

Lalu Husni, 2014, Pengantar Hukum Ketenagakerjaan, Rajawali Pers, Jakarta.

Oemar Hamalik, 2001,Proses Belajar Mengajar, Bumi Aksara, jakarta.

Ronny Hanitijo Soemantro, 1983, Metodologi Penelitian Hukum, Ghalia Indonesia, Jakarta.

Zaeni Asyhadie, 2007, Hukum Kerja: Hukum Ketenagakerjaan Bidang Hubungan Kerja, PT. Raja Grafindo Persada, Jakarta.

\section{Peraturan Perundang - undangan}

Kitab Undang-Undang Hukum Perdata, Burgelijk Wetboek, 2008, diterjemahkan oleh Subekti, R. dan Tjitrosudibio, Pradnya Paramita, Jakarta.

Undang-Undang No 13 Tahun 2003 Tentang Ketenagakerjaan, Dimuat dalam Lembaran Negara Republik Indonesia Tahun 
2013 Nomor 39, Tambahan Lembaran Negara Republik Indonesia Nomor 4279.

Undang-Undang No 2 Tahun 2004 Tentang Penyelesaian Hubungan Industrial, Lembaran Negara Republik Indonesia Tahun 2004 Nomor 6

Peraturan Mentri Tenaga Kerja dan Transmigrasi No 7 Tahun 2013 Tentang Upah Minimum, Berita Negara Republik Indonesia Tahun 2013 Nomor 1239.

Peraturan Gubernur Bali No 91 Tahun 2018 Tentang Upah Minimum Kabupaten/Kota, Berita Negara Republik Indonesia Tahun 2019 Nomor 91.

\section{Artikel Jurnal}

Noor Faiz, 2017, Kolerasi Pengaturan Upah Dengan Investasi Di Indonesia, Jurnal Magister Hukum Udayana Vol. 6, No. 3, September 2017.

https://ojs.unud.ac.id/index.php/jmhu/article/view/36110 ( diakses tgl 19 Mei 2019) 